\title{
Halomonas gudaonensis sp. nov., isolated from a saline soil contaminated by crude oil
}

\author{
Correspondence \\ Xiao-Lei Wu \\ xiaolei_wu@tsinghua.edu.cn
}

\author{
Ya-Nan Wang, ${ }^{1}$ Hua Cai, ${ }^{1}$ Su-Lin Yu, ${ }^{1}$ Zhi-Yao Wang, ${ }^{2}$ Jie Liu ${ }^{2}$ \\ and Xiao-Lei $\mathrm{Wu}^{1}$ \\ ${ }^{1}$ Department of Environmental Science and Engineering, Tsinghua University, Beijing 100084,
China \\ ${ }^{2}$ Daqing Oilfield Company Ltd, Daqing 163712, China
}

\begin{abstract}
Two moderately halophilic strains, SL014B-69 ${ }^{\top}$ and SL014B-62A2, were isolated from a saline soil contaminated with crude oil in Gudao in the coastal Shengli oilfield in China; the isolates were Gram-negative, rod-shaped and carried lateral flagella. Growth occurred at $\mathrm{NaCl}$ concentrations of $1-20 \%(\mathrm{w} / \mathrm{v})$, at temperatures of $10-42^{\circ} \mathrm{C}$ and at $\mathrm{pH}$ 8.0-9.0. Strain SL014B-69 ${ }^{\top}$ had $\mathrm{C}_{18: 1} \omega 7 \mathrm{C}$ (28.61\%), $\mathrm{C}_{19: 1}$ cyclo $\omega 7 c(27.97 \%), \mathrm{C}_{16: 0}(19.66 \%)$ and $\mathrm{C}_{12: 0} 3-\mathrm{OH}(8.87 \%)$ as the predominant fatty acids and $\mathrm{Q} 9$ as the major ubiquinone, with the $\mathrm{G}+\mathrm{C}$ content of genomic DNA being $64.0 \mathrm{~mol} \%$. Phylogenetic analyses based on $16 \mathrm{~S}$ rRNA gene sequences indicated that the two strains belonged to genus of Halomonas in the Gammaproteobacteria, with the highest $16 \mathrm{~S}$ rRNA gene sequence similarities of $96.4 \%$ with Halomonas campisalis ATCC $700597^{\top}$ and 96.0\% with Halomonas desiderata FB2 ${ }^{\top}$. DNA-DNA relatedness of strain SL014B-69 ${ }^{\top}$ with strain SL014B-62A2, H. campisalis ATCC $700597^{\top}$ and $H$. desiderata DSM $9502^{\top}$ was $97.4,42.9$ and $36.8 \%$, respectively. On the basis of these data, a novel species of the genus Halomonas, Halomonas gudaonensis sp. nov., is proposed for strain SL014B-69 ${ }^{\top}$ and SL014B-62A2. The type strain is SL014B-69 ${ }^{\top}\left(=\right.$ LMG $23610^{\top}=$ CGMCC $\left.1.6133^{\top}\right)$.
\end{abstract}

With the description of Halomonas elongata in 1980 (Vreeland et al., 1980), the species of the genus Halomonas were described as rod-shaped, Gram-negative, halotolerant bacteria with flagella that grow aerobically on a wide range of salt concentrations of $0.1-32.5 \%(w / v) ~ N a C l$ (Franzmann et al., 1987). By the end of 2005, the genus Halomonas contained almost 40 species, isolated from various environments, including saline and hypersaline lakes (Franzmann et al., 1987; Mormile et al., 1999), a saltern (Hebert \& Vreeland, 1987; Lim et al., 2004), saline wetland (MartínezCánovas et al., 2004), saline soil (García et al., 2004), a mineral pool (Romano et al., 2005), seawater (Yoon et al., 2001), seafood (Yoon et al., 2002), a deep-sea hydrothermal vent (Kaye et al., 2004) and gill tissue of an ascidian (Romanenko et al., 2002), as well as alkaline waste (Berendes et al., 1996) and a mural painting (Heyrman et al., 2002). In this study, we report the characterization of two novel strains, SL014B-69 ${ }^{\mathrm{T}}$ and SL014B-62A2, that were isolated from an oil-polluted saline soil in a coastal oilfield in eastern China. The results indicate that the two isolates represent a novel species of the genus Halomonas.

Strains SL014B-69 ${ }^{\mathrm{T}}$ and SL014B-62A2 were isolated from a saline soil from Gudao, in the Shengli oilfield of eastern

The GenBank/EMBL/DDBJ accession number for the $16 \mathrm{~S}$ rRNA gene sequence of strain SL014B-69 ${ }^{\top}$ is DQ421808.
China, that was contaminated with crude oil; they were isolated by 10 -fold dilution plating on agar plates containing only oil-produced water, and incubated for 7 days at $30^{\circ} \mathrm{C}$. The isolates were purified with restreaking on plates of artificial seawater (ASW) agar $\left(1^{-1}\right.$ : peptone, $5 \mathrm{~g}$; yeast extract, $1 \mathrm{~g} ; \mathrm{Na}_{2} \mathrm{SO}_{4}, 4 \mathrm{~g} ; \mathrm{KCl}, 0.68 \mathrm{~g} ; \mathrm{KBr}, 0.1 \mathrm{~g} ; \mathrm{H}_{3} \mathrm{BO}_{3}$, $0.025 \mathrm{~g} ; \mathrm{MgCl}_{2} . \mathrm{H}_{2} \mathrm{O}, 5.4 \mathrm{~g} ; \mathrm{CaCl}_{2} .2 \mathrm{H}_{2} \mathrm{O}, 1.5 \mathrm{~g} ; \mathrm{SrCl}_{2} \cdot 6 \mathrm{H}_{2} \mathrm{O}$, 0.024 g; $\mathrm{NaHCO}_{3}, 0.2$ g; $\mathrm{Na}_{2} \mathrm{HPO}_{4}, 0.04$ g; $\mathrm{NH}_{4} \mathrm{Cl}, 0.5$ g; $\mathrm{NaF}, 0.002 \mathrm{~g} ; \mathrm{pH}$ 8.0) with $2.4 \% \mathrm{NaCl}$ (Eguchi et al., 1996) for 2 days at $30^{\circ} \mathrm{C}$. Growth was tested at different temperatures $\left(5-50{ }^{\circ} \mathrm{C}\right)$ and at $\mathrm{pH} 2.0-12.0$ in ASW medium containing $5 \%(\mathrm{w} / \mathrm{v}) \mathrm{NaCl}$. Requirement for and tolerance of different concentrations of $\mathrm{NaCl}$ were determined in ASW medium with $\mathrm{NaCl}$ concentrations of $0-20 \%$ (w/v).

After the strains were grown to late exponential phase on ASW agar, cell morphology and flagellum type were examined using transmission and scanning electron microscopy. Oxidase activity was tested as described by Smibert \& Krieg (1994). Catalase activity was determined with $3 \%$ (v/v) hydrogen peroxide solution. Denitrification was assessed as described by Zumft (1991). Hydrolysis of starch, gelatin and Tween 80, urease activity and growth on sole carbon sources and sole nitrogen sources were examined according to Williams et al. (1983) on ASW medium after 5-7 days incubation at $30^{\circ} \mathrm{C}$. After cells of 
SL014B-69 ${ }^{\mathrm{T}}$, Halomonas campisalis ATCC $700597^{\mathrm{T}}$ and Halomonas desiderata DSM $9502^{\mathrm{T}}$ were grown on ASW agar at $30^{\circ} \mathrm{C}$ for 2 days, cellular fatty acid methyl esters were prepared and analysed using gas chromatography according to the instructions of the Microbial Identification System (MIDI). Fatty acid profiles were analysed with the Sherlock system (Microbial ID Inc.). Isoprenoid quinones were analysed as described by Komagata \& Suzuki (1987), using HPLC fitted with a reversed-phase column (Shim-pack, VPODS; Shimazu). Polar lipids were extracted and tested by one- and two-dimensional TLC on Merck silica gel $60 \mathrm{~F}_{254}$ aluminium-backed thin-layer plates according to the methods of Kates (1986) and Collins et al. (1980).

Genomic DNA was extracted and purified by the method of Marmur (1961) from cells grown in ASW medium for 2 days at $30{ }^{\circ} \mathrm{C}$. The purity was assessed from the $A_{280} / A_{260}$ and $A_{230} / A_{260}$ ratios (Johnson, 1994). The $\mathrm{G}+\mathrm{C}$ content of genomic DNA was determined by thermal denaturation (Marmur \& Doty, 1962) using DNA from Escherichia coli $\mathrm{K}-12$ as a control. The $16 \mathrm{~S}$ rRNA gene was amplified as described by Embley (1991) with universal bacterial primers 8F (5'-AGAGTTTGATCCTGGCTCAG) and 1492R (5'GGTTACCTTGTTACGACTT). DNA-DNA hybridization was performed in triplicate following the methods of De Ley et al. (1970) and Huß et al. (1983). The 16S rRNA gene sequence of strain SL014B- $69^{\mathrm{T}}$ was aligned with those of related Halomonas species by using the MEGA software (Kumar et al., 2004). The phylogenetic tree was constructed using the neighbour-joining method (Saitou \& Nei, 1987) available in the MEGA software package, version 5.0 (Kumar et al., 2004), and re-evaluated with the interior branch test of phylogeny.

Cells of strains SL014B-69 ${ }^{\mathrm{T}}$ and SL014B-62A2 were Gramnegative rods, $0.3-0.4 \times 0.75-1.65 \mu \mathrm{m}$, with a lateral flagellum. Spores were not present (Fig. 1). The two isolates formed creamy, smooth, irregular circular colonies on ASW agar. The ranges of $\mathrm{NaCl}$ concentration, $\mathrm{pH}$ and temperature for growth were 1-20 \% NaCl (w/v) (optimum 10-15\% $\mathrm{NaCl}$ ), $\mathrm{pH} 8.0-9.0$ (optimum $\mathrm{pH} 8.0$ ) and $10-42{ }^{\circ} \mathrm{C}$ (optimum $30^{\circ} \mathrm{C}$ ). The isolates were positive for oxidase, catalase, urease and denitrifying activities, but negative for hydrolysis of gelatin, starch and Tween 80 . The other main characteristics that differentiate the strains from other type strains of Halomonas are listed in Table 1 and in the species description.

Nearly complete $16 \mathrm{~S}$ rRNA gene sequences were determined for strains SL014B-69 ${ }^{\mathrm{T}}$ and SL014B-62A2. Phylogeny of the $16 \mathrm{~S}$ rRNA gene sequences revealed that strains SL014B-69 ${ }^{\mathrm{T}}$ and SL014B-62A2 were members of the Gammaproteobacteria and had a close phylogenetic relationship with the species of the genus Halomonas (Fig. 2). The 16S rRNA gene sequence of strain SL014B-69 ${ }^{\mathrm{T}}$ showed 100, 96.4 and $96.0 \%$ sequence similarity with those of strain SL014B-62A2, $H$. campisalis ATCC $700597^{\mathrm{T}}$ and $H$. desiderata $\mathrm{FB} 2^{\mathrm{T}}$, respectively. Whole-genome DNA-DNA hybridization was carried out between strains SL014B-69 ${ }^{\mathrm{T}}$ and SL014B-62A2, $H$. campisalis ATCC $700597^{\mathrm{T}}$ and $H$. desiderata DSM $9502^{\mathrm{T}}$. The DNA-DNA relatedness values for strain SL014B-69 ${ }^{\mathrm{T}}$ with SL014B-62A2, H. campisalis ATCC $700597^{\mathrm{T}}$ and $H$. desiderata DSM $9502^{\mathrm{T}}$ were respectively $96.4 \%$ (SD $4.4 \%$ ), $42.9 \%$ (SD $2.7 \%$ ) and $36.8 \%$ (SD $5.2 \%$ ).

Results of the cellular fatty acid composition analysis are given in Table 2 . The predominant cellular fatty acids of strain SL014B-69 ${ }^{\mathrm{T}}$ were $\mathrm{C}_{18: 1} \omega 7 c(28.61 \%), \mathrm{C}_{19: 1}$ cyclo $\omega 7 c$ $(27.97 \%), \mathrm{C}_{16: 0}(19.66 \%), \mathrm{C}_{12: 0} 3-\mathrm{OH}(8.87 \%)$, which are characteristic of Halomonas species. In contrast with other closely related Halomonas species, strain SL014B-69 contained a distinct unknown fatty acid ECL 11.799 (2.98\%) and did not have $\mathrm{C}_{14: 0}$ (Table 2). The major polar lipids of strain SL014B-69 $9^{\mathrm{T}}$ included phosphatidylglycerol, diphosphatidylglycerol, phosphatidylethanolamine and, distinctively, an unknown glycolipid that was not detected in H. campisalis ATCC $700597^{\mathrm{T}}$ or H. desiderata DSM $9502^{\mathrm{T}}$ (Fig. 3). The predominant isoprenoid quinone in strain SL014B-69 ${ }^{\mathrm{T}}$ was ubiquinone with nine isoprene units (Q9). The DNA G + C content of strain SL014B-69 ${ }^{\mathrm{T}}$ was $64.0 \mathrm{~mol} \%$, which is in the range reported previously for Halomonas (52-68 mol\%; Franzmann et al., 1987).

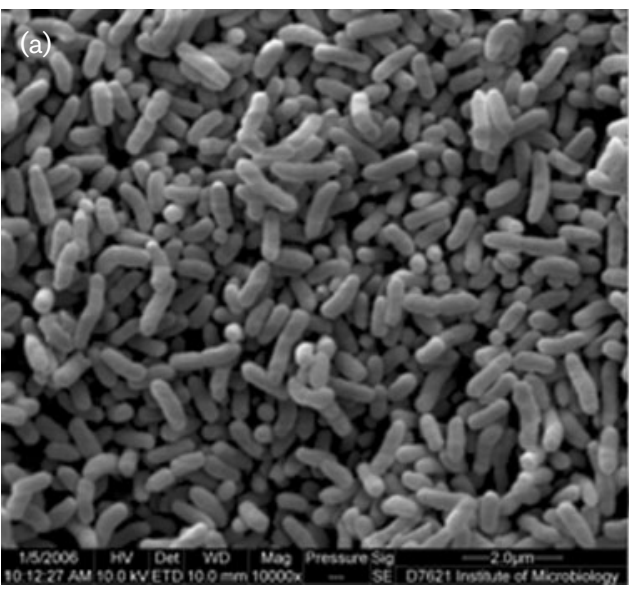

(b)
Fig. 1. Scanning electron micrograph of cells (a) and electron micrograph of a negatively stained cell (b) of strain SL014B-69'. Bars, $2.0 \mu \mathrm{m}$.

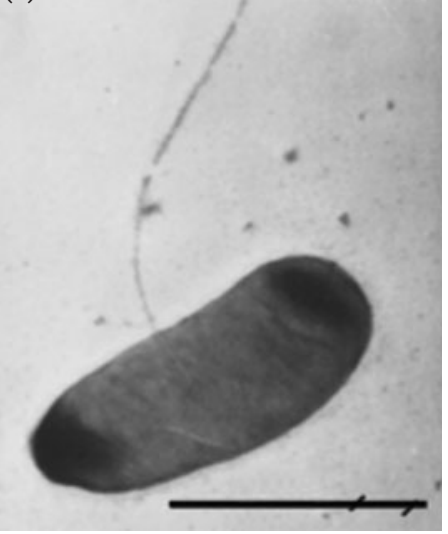


Table 1. Characteristics that differentiate strain SL014B $-69^{\top}$ from closely related Halomonas type strains

Data for carbon utilization are from the present study and from Berendes et al. (1996) and Mormile et al. (1999). All strains are Gram-negative rods, positive for catalase, oxidase and denitrification activities and utilization of sucrose, trehalose, ethanol, glycerol, acetate and gluconate. All strains are negative for hydrolysis of gelatin, starch and Tween 80 and utilization of cellobiose and D-xylose. -, Negative; + , positive; $+/-$, weakly positive.

\begin{tabular}{|c|c|c|c|}
\hline Characteristic & SL014B-69 ${ }^{\mathrm{T}}$ & $\begin{array}{c}\text { H. desiderata } \\
\text { DSM } 9502^{\mathrm{T}}\end{array}$ & $\begin{array}{l}\text { H. campisalis } \\
\text { ATCC } 700597^{\mathrm{T}}\end{array}$ \\
\hline Cell size $(\mu \mathrm{m})$ & $0.30-4.0 \times 0.75-1.65$ & $0.4-0.6 \times 0-2.6$ & $1.0 \times 3-5$ \\
\hline Flagellum & Lateral & Peritrichous & Absent \\
\hline \multicolumn{4}{|l|}{ Growth temperature $\left({ }^{\circ} \mathrm{C}\right)$} \\
\hline Optimum & 30 & 37 & 30 \\
\hline Range & $10-42$ & $10-45$ & $4-50$ \\
\hline \multicolumn{4}{|l|}{$\mathrm{pH}$ for growth } \\
\hline Optimum & 8.0 & 9.7 & 9.5 \\
\hline Range & $8.0-9.0$ & $7.0-11.0$ & $6.0-11.0$ \\
\hline \multicolumn{4}{|c|}{$\mathrm{NaCl}$ concentration for growth (\%) } \\
\hline Optimum & $10.0-15.0$ & 9.0 & 8.0 \\
\hline Range & $1.0-20.0$ & $0-18.0$ & $1.0-20.0$ \\
\hline \multicolumn{4}{|l|}{ Growth on: } \\
\hline D-Glucose & + & + & $+1-$ \\
\hline Galactose & + & $+1-$ & - \\
\hline Mannose & + & + & - \\
\hline Fructose & - & - & + \\
\hline Maltose & + & + & - \\
\hline L-Arabinose & - & $+1-$ & - \\
\hline Ribose & - & $+1-$ & - \\
\hline Lactose & + & $+1-$ & - \\
\hline Dextrin & $+1-$ & + & $+1-$ \\
\hline Mannitol & + & + & $+1-$ \\
\hline Lactate & + & $+1-$ & $+1-$ \\
\hline Hydrolysis of urea & + & - & + \\
\hline DNA G $+\mathrm{C}$ content $(\mathrm{mol} \%)$ & 64.0 & 66.0 & 66.0 \\
\hline
\end{tabular}

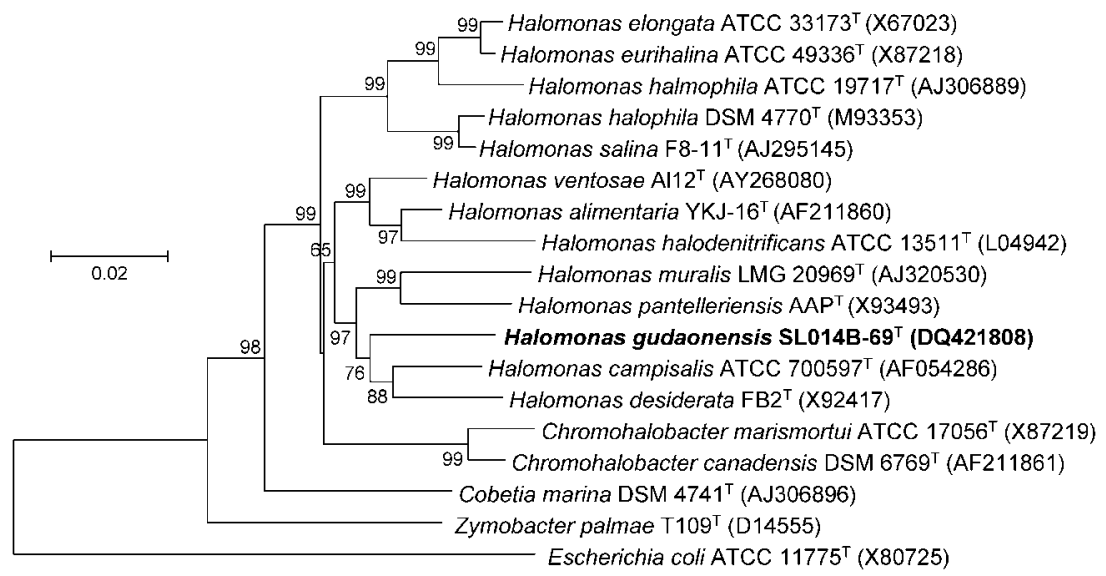

Fig. 2. Phylogenetic tree based on $16 \mathrm{~S}$ rRNA gene sequences showing the relationship between members of the genus $\mathrm{Halo-}$ monas and related genera within the family Halomonadaceae. Bootstrap values (\%) are based on 1000 replicates and are shown for branches with more than $50 \%$ bootstrap support. Bar, 0.02 expected changes per site. 
Table 2. Major cellular fatty acids (\%) of strain SL014B$69^{\top}$ and related type strains

\begin{tabular}{|lrcc|}
\hline Fatty acid & $\begin{array}{c}\text { SL014B- } \\
\mathbf{6 9}^{\mathbf{T}}\end{array}$ & $\begin{array}{c}\text { H. desiderata } \\
\text { DSM 9502 }^{\mathbf{T}}\end{array}$ & $\begin{array}{c}\text { H. campisalis } \\
\text { ATCC 700597 }^{\mathrm{T}}\end{array}$ \\
\hline $\mathrm{C}_{10: 0}$ & 0.98 & 1.83 & 2.76 \\
Unknown 11.799 & 2.98 & & \\
$\mathrm{C}_{12: 0}$ & 1.25 & & 0.86 \\
$\mathrm{C}_{12: 0}$ 3-OH & 8.87 & 6.27 & 5.87 \\
$\mathrm{C}_{14: 0}$ & & 3.03 & 3.35 \\
Sum in feature 3 & 4.44 & 1.77 & 8.07 \\
$\mathrm{C}_{16: 0}$ & 19.66 & 18.03 & 16.44 \\
$\mathrm{C}_{17: 0}$ cyclo & 2.70 & 1.12 & 2.96 \\
$\mathrm{C}_{17: 0}$ & 0.56 & 0.42 & 0.28 \\
$\mathrm{C}_{18: 0}$ & 0.65 & 0.84 & \\
$\mathrm{C}_{18: 1} \omega 7 c$ & 28.61 & 35.58 & 49.12 \\
$11-$ Methyl $\mathrm{C}_{18: 1} \omega 7 c$ & 0.82 & 0.78 & \\
$\mathrm{C}_{19: 1}$ cyclo $\omega 7 c$ & 27.97 & 29.68 & 10.28 \\
$\mathrm{C}_{20: 2} \omega 6,9 c$ & 0.51 & 0.65 & \\
\hline
\end{tabular}

Based on phenotypic and genotypic data, strains SL014B$69^{\mathrm{T}}$ and SL014B-62A2 are clearly distinguishable from their closest phylogenetic relatives and other species of the genus Halomonas. It is therefore proposed that strains SL014B-69 ${ }^{\mathrm{T}}$ and SL014B-62A2 represent a novel species of the genus Halomonas, for which we propose the name Halomonas gudaonensis sp. nov.
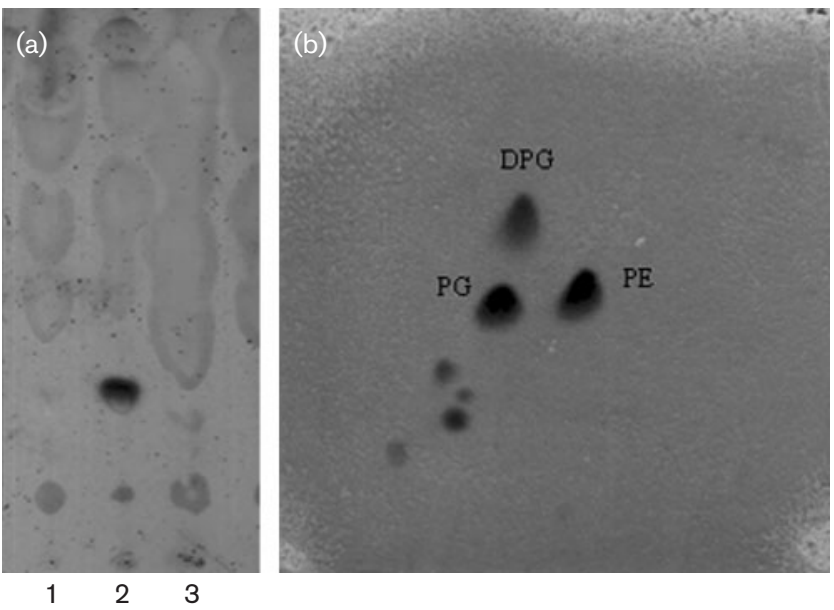

Fig. 3. (a) One-dimensional TLC of glycolipids of $H$. campisalis ATCC $700597^{\top}$ (lane 1), strain SL014B-69 ${ }^{\top}$ (lane 2) and $H$. desiderata DSM $9502^{\top}$ (lane 3). (b) Two-dimensional TLC of phospholipids from strain SL014B-69 ${ }^{\top}$. DPG, Diphosphatidylglycerol; PE, phosphatidylethanolamine; PG, phosphatidylglycerol. Phospholipids were detected by spraying the plate with Zinzadze reagent (Kates, 1986). TLC was carried out on Merck silica gel $60 \mathrm{~F}_{254}$ aluminium-backed thin-layer plates. Plates were subjected to development in chloroform/methanol/water ( $65: 25: 4$, by vol.) (first dimension) followed by chloroform/ methanol/acetic acid/water ( $85: 12: 15: 4$, by vol.) [second dimension in (b)].
Description of Halomonas gudaonensis sp. nov.

Halomonas gudaonensis (gu.dao.nen'sis. N.L. fem. adj. gudaonensis pertaining to Gudao, in the Shengli oilfield, PR China, where the type strain was isolated).

Cells are Gram-negative, aerobic rods $(0.3-0.4 \times 0.75-$ $1.65 \mu \mathrm{m}$ ) with lateral flagella. Colonies on ASW medium are creamy, circular, smooth, opaque and approximately $1.5-2 \mathrm{~mm}$ in diameter after incubation at $30^{\circ} \mathrm{C}$ for 2 days. Growth occurs at temperatures of $10-42{ }^{\circ} \mathrm{C}$ (optimum $30{ }^{\circ} \mathrm{C}$ ), at $\mathrm{NaCl}$ concentrations of $1.0-20.0 \%$ (optimum $10.0-15.0 \%)$ and at $\mathrm{pH}$ 8.0-9.0. Positive for catalase, oxidase, urease and denitrifying activities. Negative for hydrolysis of Tween 80, starch and gelatin. The following substrates are utilized as sole carbon sources for growth: D-glucose, galactose, mannose, sucrose, maltose, trehalose, lactose, dextrin, ethanol, glycerol, mannitol, lactate, acetate and gluconate. Fructose, cellobiose, L-arabinose, D-xylose and ribose are not utilized. The following substrates are utilized as sole nitrogen sources for growth: L-alanine, glutamine, isoleucine, L-proline and arginine. Lysine and glycine are not utilized. The predominant isoprenoid quinine is Q9 and the cellular polar lipids are phosphatidylglycerol, diphosphatidylglycerol, phosphatidylethanolamine and an unknown glycolipid. The major cellular fatty acids are $\mathrm{C}_{18: 1} \omega 7 c(28.61 \%), \mathrm{C}_{19: 1}$ cyclo $\omega 7 c(27.97 \%)$, $\mathrm{C}_{16: 0}(19.66 \%)$ and $\mathrm{C}_{12: 0} 3-\mathrm{OH}(8.87 \%)$. The DNA G + C content is $64.0 \mathrm{~mol} \%$.

The type strain, SL014B- $69^{\mathrm{T}}\left(=\mathrm{LMG} 23610^{\mathrm{T}}=\mathrm{CGMCC}\right.$ $1.6133^{\mathrm{T}}$ ), was isolated from a saline soil contaminated by crude oil, collected from Gudao oil-product from the coastal Shengli oilfield in China.

\section{Acknowledgements}

The type strain of $H$. campisalis was a generous gift from Dr M. R. Mormile. The authors would like to thank G.-F. Zhao, B. Guo and Y.-F. Guo for their valuable help. This study was supported by National Natural Science Foundation of China (30300008) and National Basic Research Program of China (2005CB221308).

\section{References}

Berendes, F., Gottschalk, G., Heine-Dobbernack, E., Moore, E. R. B. \& Tindall, B. J. (1996). Halomonas desiderata sp. nov., a new alkaliphilic, halotolerant and denitrifying bacterium isolated from a municipal sewage works. Syst Appl Microbiol 19, 158-167.

Collins, M. D., Goodfellow, M. \& Minnikin, D. E. (1980). Fatty acid isoprenoid quinine and polar lipid composition in the classification of Curtobacterium and related taxa. J Gen Microbiol 118, 29-37.

De Ley, J., Cattoir, H. \& Reynaerts, A. (1970). The quantitative measurement of DNA hybridization from renaturation rates. Eur J Biochem 12, 133-142.

Eguchi, M., Nishikawa, T. \& Macdonald, K. (1996). Responses to stress and nutrient availability by the marine ultramicrobacterium Sphingomonas sp. strain RB2256. Appl Environ Microbiol 62, 1287-1294. 
Embley, T. M. (1991). The linear PCR reaction: a simple and robust method for sequencing amplified rRNA genes. Lett Appl Microbiol 13, 171-174.

Franzmann, P. D., Burton, H. R. \& McMeekin, T. A. (1987). Halomonas subglaciescola, a new species of halotolerant bacteria isolated from Antarctica. Int J Syst Bacteriol 37, 27-34.

Garcia, M. T., Mellado, E., Ostos, J. C. \& Ventosa, A. (2004). Halomonas organivorans sp. nov., a moderate halophile able to degrade aromatic compounds. Int J Syst Evol Microbiol 54, 1723-1728.

Hebert, A. M. \& Vreeland, R. H. (1987). Phenotypic comparison of halotolerant bacteria: Halomonas halodurans sp. nov., nom. rev., comb. nov. Int J Syst Bacteriol 37, 347-350.

Heyrman, J., Balcaen, A., De Vos, P. \& Swings, J. (2002). Halomonas muralis sp. nov., isolated from microbial biofilms colonizing the walls and murals of the Saint-Catherine chapel (Castle Herberstein, Austria). Int J Syst Evol Microbiol 52, 2049-2054.

Huß, V. A. R., Festl, H. \& Schleifer, K.-H. (1983). Studies on the spectrometric determination of DNA hybridisation from renaturation rates. Syst Appl Microbiol 4, 184-192.

Johnson, J. L. (1994). Similarity analysis of DNAs. In Methods for General and Molecular Bacteriology, pp. 655-681. Edited by P. Gerhardt, R. G. E. Murray, W. A. Wood \& N. R. Krieg. Washington, DC: American Society for Microbiology.

Kates, M. (1986). Techniques of Lipidology, 2nd edn. Amsterdam: Elsevier.

Kaye, J. Z., Márquez, C., Ventosa, A. \& Baross, J. A. (2004). Halomonas neptunia sp. nov., Halomonas sulfidaeris sp. nov., Halomonas axialensis sp. nov. and Halomonas hydrothermalis sp. nov.: halophilic bacteria isolated from deep-sea hydrothermal-vent environments. Int J Syst Evol Microbiol 54, 499-511.

Komagata, K. \& Suzuki, K. (1987). Lipid and cell wall analysis in bacterial systematics. Methods Microbiol 19, 161-206.

Kumar, S., Tamura, K. \& Nei, M. (2004). MEGA3: integrated software for molecular evolutionary genetics analysis and sequence alignment. Brief Bioinform 5, 150-163.

Lim, J.-M., Yoon, J.-H., Lee, J.-C., Jeon, C. O., Park, D.-J., Sung, C. \& Kim, C.-J. (2004). Halomonas koreensis sp. nov., a novel moderately halophilic bacterium isolated from a solar saltern in Korea. Int J Syst Evol Microbiol 54, 2037-2042.

Marmur, J. (1961). A procedure for the isolation of deoxyribonucleic acid from micro-organisms. J Mol Biol 3, 208-218.
Marmur, J. \& Doty, P. (1962). Determination of the base composition of deoxyribonucleic acid from its thermal denaturation temperature. J Mol Biol 5, 109-118.

Martínez-Cánovas, M. J., Béjar, V., Martínez-Checa, F. \& Quesada, E. (2004). Halomonas anticariensis sp. nov., from Fuente de Piedra, a saline-wetland wildfowl reserve in Málaga, southern Spain. Int J Syst Evol Microbiol 54, 1329-1332.

Mormile, M. R., Romine, M. F., Garcia, M. T., Ventosa, A., Bailey, T. J. \& Peyton, B. M. (1999). Halomonas campisalis sp. nov., a denitrifying, moderately haloalkaliphilic bacterium. Syst Appl Microbiol 22, 551-558.

Romanenko, L. A., Schumann, P., Rohde, M., Mikhailov, V. V. \& Stackebrandt, E. (2002). Halomonas halocynthiae sp. nov., isolated from the marine ascidian Halocynthiae aurantium. Int J Syst Evol Microbiol 52, 1767-1772.

Romano, I., Giordano, A., Lama, L., Nicolaus, B. \& Gambacorta, A. (2005). Halomonas campaniensis sp. nov., a haloalkaliphilic bacterium isolated from a mineral pool of Campania Region, Italy. Syst Appl Microbiol 28, 610-618.

Saitou, N. \& Nei, M. (1987). The neighbor-joining method: a new method for reconstructing phylogenetic trees. Mol Biol Evol 4, 406-425.

Smibert, R. M. \& Krieg, N. R. (1994). Phenotypic characterization. In Methods for General and Molecular Bacteriology, pp. 607-654. Edited by P. Gerhardt, R. G. E. Murray, W. A. Wood \& N. R. Krieg. Washington, DC: American Society for Microbiology.

Vreeland, R. H., Litchfield, C. D., Martin, E. L. \& Elliot, E. (1980). Halomonas elongata, a new genus and species of extremely salttolerant bacteria. Int J Syst Bacteriol 30, 485-495.

Williams, S. T., Goodfellow, M., Alderson, G., Wellington, E. M. H., Sneath, P. H. A. \& Sackin, M. J. (1983). Numerical classification of Streptomyces and related genera. J Gen Microbiol 129, 1743-1813.

Yoon, J.-H., Choi, S. H., Lee, K.-C., Kho, Y. H., Kang, K. H. \& Park, Y.-H. (2001). Halomonas marisflavae sp. nov., a halophilic bacterium isolated from the Yellow Sea in Korea. Int J Syst Evol Microbiol 51, 1171-1177.

Yoon, J.-H., Lee, K.-C., Kho, Y. H., Kang, K. H., Kim, C.-J. \& Park, Y.-H. (2002). Halomonas alimentaria sp. nov., isolated from jeotgal, a traditional Korean fermented seafood. Int J Syst Evol Microbiol 52, 123-130.

Zumft, W. G. (1991). The denitrifying bacteria. In The Prokaryotes. A Handbook on the Biology of Bacteria: Ecophysiology, Isolation, Identification, Application, 2nd edn, pp. 554-582. Edited by A. Balows, H. G. Trüper, M. Dworkin, W. Harder \& K. H. Schleifer. New York: Springer. 